\title{
Vocal-Instrumental Style in Judith Lang Zaimont's The Figure String Quartet
}

\section{Kheng K. Koay}

The String Quartet, The Figure (2007), is a major work by Zaimont (b. 1945) and was awarded in 2015 The American Prize in Composition, professional chamber music division. The piece has a distinct, unparalleled musical language, and certainly brings out the voice of Zaimont. The quartet was commissioned by the Andrew W. Mellon Foundation, and was premiered by The Harlem Quartet at Syracuse University, Eastman School of Music and Cornell University in September, 2007.

In The Figure Zaimont freely designs and experiments with musical techniques with which she is familiar. Many interesting ideas are raised in the music, showing her distinct idioms that have led to a noticeable stylistic break with her contemporaries. Not only are instrumental characters and idioms coloristic of the music, but much of the attention in the composition is also focused on ideas that can be derived from her vocal works. The quartet demonstrates a style of music features that combine both instrumental and vocal characters, revealing Zaimont's intriguing compositional style.

This study therefore examines how Zaimont creatively experiments with and expresses vocal ideas and styles in her instrumental music; how she develops the music over the length of the quartet; and how she combines the somewhat different writing styles of two genres in the piece. Zaimont certainly has something new and interesting to offer, as she notes: "in order for a piece to succeed as a document of expression, the composer must speak meaningfully - in musical terms - and should articulate with a distinctive musical voice." ${ }^{\text {This }}$ paper also will discuss three of Zaimont's vocal works that present a similar compositional approach used in the quartet: Virgie Rainey (2002), Nattens Monolog - Night Soliloquy (1984), and In the Theatre of Night (1983).

Experimenting with vocal writing styles in instrumental music is heard in many $19^{\text {th }}$-century music pieces, such as in Mendelssohn's piano work Song

\footnotetext{
${ }^{1}$ Judith Lang Zaimont, "Being a Composer - Ruminations on an Undescribable Art." Keynote speech for March 2002 Minnesota Classical Music Listening List. (Accessed: 27 June, 2017) http:// www.jzaimont.com/bibliography/bibliography-on-being-a-composer.html
} 
Without Words, no. 1, op. 19, no. 1, and Beethoven's Cavatina in his String Quartet in B flat major, op. 130. However, this experimentation has changed over time. Composers have not only discovered various ways that capture and imitate song characters in instrumental works for desired effects and moods, but also have come up with musical designs and structures that may remind one of a vocal work, aiming for new compositional creations. Further, various technical approaches also have been employed to find a balance between vocal and instrumental styles.

In Zaimont's quartet, diverse ways of musical handlings are utilized, experimenting with and imitating characteristics that are reminiscent of vocal writings. She places much consideration on the expressive implications in the piece and explores a wide range of expressions. Her employment of vocal color is aimed at creating moods in the work. Specific instructions and indications given are important in conveying emotional quality in the music. As in her vocal compositions, Zaimont has a clear idea of how she wants her music to sound. Although highly chromatic in sound, the quartet vibrates with excited emotion and musical activity. In addition, in her own music language she experiments with an operatic style of vocal accompaniment. The quartet is tempered with expressiveness, gracefulness and lyrical melodic lines.

Indeed, in her compositions, Zaimont has developed her own musical character with her compositional style, once saying that "one must be true to one's self, that you cannot write music with master composers of the past sitting over your shoulder, that you need to write a kind of music that is genuine, substantive, and moving to you, and not cater necessarily to an international style which doesn't fit you very well." ${ }^{2}$ Her music is ear-catching. In this quartet, not only mood and emotion are heavily stressed to create dramatic effects, but excitement of the music also is simultaneously built by rhythmic articulation. Performance markings and directions significantly play a role in shaping the music throughout the composition. Instrumental idiomatic is also employed to create coloristic sound color in the music. Different expressive characters and styles of music are juxtaposed, demonstrating various compositional approaches by Zaimont. The composition is full of her personal musical imagination.

Throughout the quartet Zaimont also utilizes strong musical returning material for cohesiveness in the music. Not only does she unite the composition with her regular use of a small group of pitches in repeating character throughout, but also through the use of motivic development. Each end of an idea in the music

${ }^{2}$ Carol Ann O’Connor, “A Comparative Stylistic Analysis of Selected Solo Vocal Works by Twentieth-Century American Women Composers: Barbara Kolb, Ruth Lomon, and Judith Lang Zaimont" (diss., University of Connecticut, 1996), 280. 
is carefully designed; pauses, note values and textural change play an important role, providing more sense of directional characteristics in the music. Climaxes are carefully set up with growing intensity in rhythms and pitches. A recurring pitch pattern or rhythm in a similar pattern reflects the minimalist musical style. Embracing flexibility in her music, she also has remained open to the pop music culture, with writings here in the quartet also reflecting some American pop idioms, thus creating a hybrid of musical styles.

\section{Zaimont's Music Perceptions and Achievements}

Throughout her creative output Zaimont shows her ability to communicate with her listeners and to bring out her own voice. Her aim of musical interest to listeners is the creation of lovely melodies and listening experiences. "I want listening to be an intensely involving experience for my audience, and in part that's my nature," said Zaimont. ${ }^{3}$ She also stresses that "a piece of music, if it is going to live, has to be susceptible to different people's understandings." ${ }^{4}$ Zaimont's approach to composition and her stylistic maturation has progressed in relation to her study of the music from past composers. She is familiar with the music of Ravel, Stravinsky, Tchaikovsky, and Brahms, having once said that she writes more like these people whose orchestration she had studied. ${ }^{5}$

Zaimont is also attracted to the Russian and French music lines of descent: "the orchestral models I most admire are those of the Russian-French lineage. Here (as in Berlioz), one finds an emphasis on brilliance and drama, with fast harmonic rhythm thrown in for good measure. (For me a breathtakingly exciting musical experience)." ${ }^{6}$ There are also others who inspired Zaimont to be a composer; she says, "distinct from my first attempts to create new music, my awakening as a composer came from signals from three composers whom I'd never met, two of whom were already dead. The composers were Chopin, Prokofiev and Copland."

Zaimont's stylistic growth is also influenced by her teachers, such as Hugo Weisgall at Queens College, and Jack Beeson and Otto Leuning at Columbia.

\footnotetext{
${ }^{3}$ Sharon Llewellyn, "Amy Beach and Judith Lang Zaimont: A Comparative Study of Their Lives and Song” (diss., Arizona State University, 2008). (Ann Arbor: UMI, 2008, 3338442), 448.

${ }^{4}$ Ann Kilstofte, "An Interview with Judith Lang Zaimont: The Dual Process of the Cliburn Competition," Journal of the International Alliance for Women in Music, vol. 7, no. 3 (Fall 2001): 6. (Accessed: 24 July, 2017) http://www.jzaimont.com/bibliography/iawm-1.jpg

${ }^{5}$ Susan Lynn Baird, "The Choral Music of Judith Lang Zaimont” (diss., Florida State University, 1991), 272.

6 "Electronic Dialogue/1: Judith Lang Zaimont” Sequenza/21 (Accessed: 27 June, 2017) http://www. sequenza21.com/Zaimont.html

${ }^{7}$ Zaimont, "Being a Composer."
} 
"Weisgall and Beeson may have influenced me, since I write a tremendous amount of music for voice, and they both are heavily concentrated in vocal music. Leuning gave me a wonderful sense of anything goes - one need not wear a stylistic strait-jacket."

Indeed, various musical idioms and characteristics demonstrate the uniqueness of her works. Being a prolific composer, Zaimont has been a Guggenheim Foundation Fellow, an Aaron Copland Award winner, and has enjoyed a distinguished career as a composer whose works have been performed by the Philadelphia Orchestra, the Baltimore and Mississippi Symphonies, Berlin and Czech Radio Symphonies, the Slovak National Philharmonic, and the Kremlin Chamber Orchestra. Her music is widely performed throughout the USA and Europe, and has been recorded for the Naxos, Koch International Classics, Harmonia Mundi, Arkiv Music, Albany, MSR Classics, Leonarda, and many others. It is also with all these achievements that one's attention is drawn to Zaimont's work, wanting to go further in exploring her musical language. Yet, surprisingly, in the last few decades very little scholarly research has been done on her music, even though today Zaimont's music has been exposed more regularly, and has received much attention.

Kyle Gann claims that Zaimont's "music is so charming and personal [...]." Her music is often "cited for its immediacy, dynamism and palpable emotion." As a composer, she finds ways to create music that is "fresh," "unexpected," "distinct," and "durable." ${ }^{11}$ There is no limit to Zaimont's composing ideas, as she claims that "anything is possible." She explains that "there are hallmarks to my style, but they are aspects of musical fabric (many-layered), treatment of materials, originality in devising forms (I don't like received ones), and most definitely a preference for developmental variation as a constant," and further claims that "nothing in my music sits still for very long. And I like textures in which there's a lot of 'stuff,' but not muddy sounds or any turgidness. Plus, the surfaces should be meticulously worked, enhancing whatever attractive quotient the materials imply." 12

${ }^{8}$ Quoted from Diane Peacock Jezic, Women Composers, second ed. (New York: The Feminist Press, 1988), 214.

${ }^{9}$ Kyle Gann, "American Composer Profile: Judith Lang Zaimont by Kyle Gann," Chamber Music Magazine (Chamber Music America), January/February 2004. (Accessed: 24 July, 2017) http://www. jzaimont.com/bibliography/bibliography-gann.html

${ }^{10}$ Quoted from CD Booklet written by Jeffrey W. James, Judith Lang Zaimont: Chroma - Northern Lights, Ghosts, Elegy, Stillness performance by Slovak National Symphony Orchestra, conducted by Kirk Trevor. Disc. 2008, Naxos 8.559619.

${ }^{11}$ Joe Brumbeloe, “A Conversation with Judith Lang Zaimont by Joe Brumbeloe," 2010 (Accessed: 27 June, 2017) http://www.agocal.org/music/reviews/rv1112/zaimont.html

${ }^{12}$ Ibid. 
Zaimont accepts change and flexibility as a part of her music creativity. This motivating approach and the ideas in musical writings came through her encounter with Chopin's Mazurkas and all the Nocturnes during her teens:

I'd start at the front of the book, and finish at the back, playing everything. In doing this, I realized that Chopin was also impatient: He never comes back to restate his material exactly, precisely the same way - every repetition gets adjusted somehow, which to me was a signal to say it's $\mathrm{OK}$ to mess around with the notes: You don't have to do it the way you did it at first - tweak it, re-imagine it, recompose it. ${ }^{13}$

Zamont also welcomes the unexpected occurring in the music during her compositional writing process of a piece; she remarks that,

What I personally value in music is that it opens up a "window" into the unexpected: that it makes me listen closely because it's going somewhere I can't anticipate. So much 18th-century music to me is of little appeal, because the balanced-period phrase structures drive the music absolutely, to the detriment of harmonic venturing (or misleading) and rhythmic refreshments. Indeed, of the traditional three musical elements - Melody, Harmony, Rhythm - melody is the last one to grab me. (And I'm known for writing melodies!! - go figure...). Vital, surprising rhythms are first, with the sensuous appeal of harmony a close second. ${ }^{14}$

In the search for new and individual musical language, Zaimont claims that "a composer has to shove aside all external static, and look to discover and hone the essence of a PERSONAL COMPOSITIONAL voice. Ideally, this voice is stylistically distinct, well-inflected, complete, and true." ${ }^{15}$ Zaimont composes not merely for the premier of her works but for her contribution to the music repertoire. "If I am not writing something I firmly believe will be durable and a prime addition to repertoire, I won't even begin to work on the piece." ${ }^{" 6}$ She hears beauty in individual instrumental sound colors and explores every possibility to create excitement and deliver messages in music to her listeners. "Specific instrumental colors or timbral combinations can by themselves signal a musical environment meant to be heard as beguiling or seductive. Likewise, immediate connotations arise from juxtaposing pillared harmonies and flanking silences.

\footnotetext{
${ }^{13}$ Zaimont, "Being a Composer."

14 "Electronic Dialogue/1: Judith Lang Zaimont” Sequenza/21.

${ }^{15}$ Judith Lang Zaimont, "Reflections on an Undescribable Art - Being a Composer," Minnesota Listening List Competition keynote speech delivered at Augsburg College on February 8, 2002. (Accessed: 24 July, 2017) http://www.jamesarts.com/releases/feb02/JLZ_021202.htm

${ }^{16}$ Susan Cohn Lackman, "Judith Lang Zaimont: Part 1, Profile," Journal of LAWM, vol. 19, no. 2 (2013): 2 .
} 
Even the choice to emphasize sheer flow immediately sends a clear message to the listener," said Zaimont. ${ }^{17}$ Indeed, the sensuous quality of sound is essential for Zaimont. "I don't like filler in music. I like everything that's down there to be important [...]. I want listening to be an intensely involving experience for my audience, and in part that's my nature, which bleeds through to the nature of the music." 18

Zaimont always aims to make music interesting by exploring greater emotional and dramatic intensities. This can be clearly heard both in her vocal and instrumental compositions written after the 1980s. Zaimont herself says her music contains "drama" and "passion," ${ }^{19}$ and that sound colors are essential in her music. "Very definitely, I hear the particular colors in my head [when composing]: I always have," said Zaimont. ${ }^{20}$ To the composer, every intention and instruction is given on the score, the performer should "not be daunted [by the] technical challenges ... [because] they're not inserted gratuitously to make a piece more challenging. If they're there, there are musical reasons why they are there." ${ }^{21}$ It is essential to Zaimont that her listeners are able to actively engage in her music. She said:

How do I compare myself, therefore, with other composers of the second half of the twentieth century? If I'm a lyric modernist and if post-modernism is now the prevailing style, I guess I am warmer and more intense, rather than adopting the slightly distanced stance and slightly cooler - maybe wry - perspective of postmodernism in music [...]. Music is a communication, and it's less important to worry over or concern oneself about other styles that are coexisting. What is most important is to insure that you are perfecting and making ever more clear what your style is, what your language is, what your syntax is. ${ }^{22}$

\section{The Figure String Quartet}

The quartet consists of two movements: I) In Shadow, and II) In Bright Light. The opening slow, two whole-note value chords of sound hold the attention of the listener, emphasizing their importance in the music. They reappear with varying rhythmic patterns throughout the first movement. Zaimont also stresses

\footnotetext{
${ }^{17}$ Judith Lang Zaimont, “The Matter of Style," Newmusicbox, August 23, 2006. (Accessed: 27 June, 2017) http://www.newmusicbox.org/articles/The-Matter-of-Style/

${ }^{18}$ Llewellyn, "Amy Beach and Judith Lang Zaimont," 448.

${ }^{19}$ Kim Atkinson, “Composer Profile: Judith Lang Zaimont," Women of Note Quarterly 3, no. 4 (November 1995): 3.

${ }^{20}$ O'Connor, A Comparative Stylistic Analysis, 285.

${ }^{21}$ Llewellyn, "Amy Beach and Judith Lang Zaimont," 446.

${ }^{22}$ Ibid., 448.
} 
the top two chromatic pitches, $\mathrm{C}-\mathrm{B}$, of the two chords in violin 1, developing them into a longer melodic line. Not only does Zaimont heavily emphasize the chromatic intervals in the music, but also very often that the $\mathrm{C}-\mathrm{B}$ is followed by pitch $\mathrm{A}$, forming a pattern of chromatic and whole-tone intervals. This chromatic-and-whole-tone intervallic pattern may not be an obvious musical feature at the beginning of the piece, but nevertheless, as the music progresses, it is used as one of the building materials to begin an idea throughout the composition, which has also become one of the characteristics in the piece and a way Zaimont unites her music as a whole.

Indeed, the unity of the piece is heard; the two pitches, C-B, return at the opening of the second movement, but are in reverse order, B-C. Although the second movement begins with an anacrusis in scotch snap rhythm (a short-long rhythmic structure), an accent is placed on the $\mathrm{B}$, catching the attention of the listener. Not only does Zaimont emphasize the B-C in the second movement, but the $\mathrm{C}-\mathrm{B}$ also reoccurs at various times in different note-values and rhythmic patterns throughout the movement, connecting her pitch ideas together in a coherent way.

In the quartet, Zaimont remarks that the two sounds are "a slow dramatic two-chord unit, not dissimilar to a sigh which, however, brings little relief." 23 The idea of a "sigh" and its relief can be heard in the two movements, which are designed to present different moods and characters. The opening slow, descending C5-B4 (based on middle C as C4) in the first movement opens the music with passion, which also is reminiscent of the "sigh" Zaimont intended to capture, while the second movement with the B4-C6 octave ascending leap illustrates energetic and angular manners, which may indicate its relief from the "sigh", turning the music to what Zaimont calls "In Bright Light" for the second movement. This musical writing is similar to a word-painting technique that uses musical gestures to reflect text meaning and is commonly employed in vocal works. Composers use musical gestures to convey the emotions suggested in the words and to reinforce the images in the text. In the past, for instance, falling thirds and semitones were used by composers to express grief and passion.

There is no strict use of traditional structures in the quartet. Zaimont once commented that she "no longer has too much interest in anything that's a traditional form." ${ }^{24}$ What interests her is the flexibility and "varied ways to make form, again in an instrumental work, meaning more precisely how not to borrow traditional forms up to the present day, but the novelist letting a character lead the novelist into how the next scene should play. How the music materials themselves

\footnotetext{
${ }^{23}$ Judith Lang Zaimont, String Quartet: The Figure, Subito Music Publishing.

${ }^{24}$ O'Connor, A Comparative Stylistic Analysis, 283.
} 
speak to me..." ${ }^{25}$ Indeed, there are always ways that Zaimont makes her musical direction in her composition, without being strictly based on traditional forms. In the quartet, the length of each presented idea is varied; nevertheless, Zaimont tends to heighten a long pause or rests at every end of an idea. To catch the attention of the listener, more often it is also preceded by either a small group of a repeating pitch, or chord-like patterns marked with ritenuto. This prepares listeners for an expectant change of idea and musical event after a break. Such musical gesture is not only one of the characteristics in the quartet, but is also a typical style of Zaimont. It appears in her vocal works, and can also be heard in her instrumental compositions such as Symphony No. 4 "Pure, Cool (Water)" (2013), Stillness (2005), and many others.

In contrast, there are also a few times when Zaimont employs a bridge or a short transitional material to link two musical events, giving a smooth musical flow. This is not merely an instrumental musical compositional technique; a similar idea is used in many vocal works, including Zaimont's songs. Preludes, interludes and postludes are inserted in the piano accompaniment of songs, giving a continuous flow in the music. Such structural design was also a common lieder writing style in the Romantic period, such as in Schumann's vocal works.

Musical gestures that contain vocal breathing indications, which not only create irregular rhythms but also give singers a chance to catch their breath, allowing them to sustain long vocal lines, are imitated in The Figure quartet. The irregular rhythms that are created by these rests and breath markings are as if there was in Zaimont's mind an attached poem or text, and each instrument is treated like a vocal part for a singer. More often the instrumental melodies with short-breath are given through irregular breath markings, caesure $(/ /)$ rests and pauses. This idea is reminiscent of vocal melodic writing styles that can be found in the lieders of composers such as Schoenberg's Four Lieder, op. 2 no.1, Webern's Five Lieder aus Der siebente Ring, op. 3, Berg's Four Gesänge, op. 2, Ravel's Sur l'herebe, Tchaikovsky's We Have Not Far to Walk, and others.

In addition, throughout her compositional career Zaimont has been preoccupied with writing vocal compositions, which include vocal genres such as chamber vocal music, opera and choral works. Her personal experience and interest in writing vocal works are as she describes:

I'm a singer manqué from the time I was in college, when I sang in chorus. I have no gift for the voice, but I have a love of words, a love of their sound as well as sense. So I was naturally drawn to setting text, grabbing after that thing I wasn't

${ }^{25}$ Llewellyn, “Amy Beach and Judith Lang Zaimont,” 441. 
blessed with. I had many invitations to write for choral groups and solo artists, and by the early to mid-80s I realized my catalog was lopsided. ${ }^{26}$

Naturally, she challenges herself by experimenting with vocal writing styles in her instrumental music and completely personalizes her interpretation. Similarly, in her vocal works one also witnesses a vocal writing tradition such as breath marking, which is flexibly used in the vocal line, and is also applied in the piano accompaniment. It's not surprising, then, that she transforms vocal ideas into her instrumental compositions, creating not only a unique quality in instrumental pieces, but also retaining her individuality in musical language.

Indeed, many of Zaimont's compositions reveal her use of vocal idioms and vocabulary. Nevertheless, at times, such short-breathed writing also brings to mind jazz music, especially of Thelonious Monk, whose melodic lines tend to be fragmented by rests. Zaimont was exposed to the music of Thelonious Monk and other jazz players during her college years. She recalls that "once I got to college, it was Thelonius Monk, Oscar Peterson, Art Tatum all the way. Their invention was at a sustained and high level, and their joy, high energy and commitment to their sound-world fueled my continuing discovery of that world as a young adult." 27

Throughout her music career Zaimont also has shown interest in rag and jazz, and has experimented with these in her compositions. "I've been consistently drawn to incorporating jazz rhythms. (They pop up both overtly and covertly in quite a number of my pieces.) Ragtime also; four movements in rag idiom so far, with a fifth in progress...," she explained, ${ }^{28}$ adding that "the new series will add in some of my more playful music. I've been writing concert versions of ragtime since the late'70s." 29 In her compositions - for instance Hesitation Rag (1998), "Jazz Waltz" in Suite Impressions (1994) and Two Piano Rags: "Reflective Rag", "Judy's Rag"(1974) and Snazzy sonata (1972) - Zaimont employs characteristics of pop styles such as syncopated rag rhythm, off beat accents, and jazzy. The Snazzy sonata is "absolute nostalgia for an American past that's very real to me,

\footnotetext{
${ }^{26}$ Quoted from Joo Won Jun, "The Compositions of Judith Lang Zaimont as found in Nattens Monolog (Night Soliloquy), Scena for Soprano Voice and Piano with the Text by Dag Hammarskjöld” (diss., Louisiana State University, 2005), 3 https://digitalcommons.lsu.edu/cgi/viewcontent.cgi?referer=https://www.google.com.tw/\&httpsredir=1\&article=2420\&context=gradschool_dissertations ${ }^{27}$ Brumbeloe, "A Conversation with Judith Lang Zaimont."

28 "Electronic Dialogue/1: Judith Lang Zaimont" Sequenza/21.

${ }^{29}$ Raquel Hendrickson, "International Events, acclaim accompany Maricopa composer," InMaricopa News, November 9, 2015. (Accessed: 27 June, 2017) https://www.inmaricopa.com/tag/judith-langzaimont/
} 
although I know it only through history," said Zaimont. ${ }^{30}$ It is not surprising, then, that she experiments in the quartet with music characteristics that bring to mind some jazz idioms.

As in the vocal genre, in which a wide variety of emotions can be covered in a single work, here in the quartet different moods and emotions unfold as the music progresses, enhancing interesting and dramatic musical passages. For instance, in the first movement of the quartet beginning at measure 182 Zaimont portrays her personal musical imagination, projecting violin 1 as a singer that sings with an emotional hesitancy, with slowness and expressiveness. Decreasing soft dynamics are placed at the end of each break, stressing very short musical statements ending with the feeling of uncertainty. Zaimont uses four measures to capture the mood of hesitation. Rests, breath markings and pauses are inserted to interrupt the melodic flow in the music (Example 1), giving the sense of hesitancy and reluctance. Such music handling has been used in her songs such as "Narrative 1" from Virgie Rainey, and Nattens Monolog - Night Soliloquy.

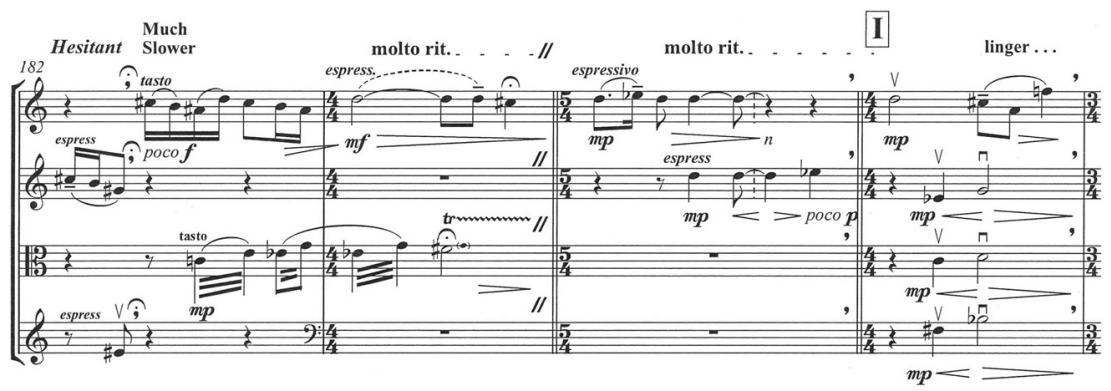

Example 1

In the second movement of the quartet, when conveying a different effect such as a mysterious mood, Zaimont applies more tremoli playing in violins and viola against long sustaining, tie-notes in cello (Example 2). Not only do high register pitches gradually descend to a lower register, but the dynamic levels also slowly decrease from poco forte to pianissimo, indicating an end of an idea. The regular change of moods and emotions is also commonly found in her vocal work and instrumental music. In her vocal compositions, Zaimont not only allows listeners to anticipate the expressive feeling in connection to the text, but also to enjoy the beauty of the music, which goes through moments of high dramatic effects and emotions.

${ }^{30}$ Quoted from CD Booklet written by Judith Lang Zaimont, Summer Melodies: A Piano Album by Judith Lang Zaimont, performance by Judith and Doris Lang Zaimont. 4 Tay Inc., 1995. CD4001. 


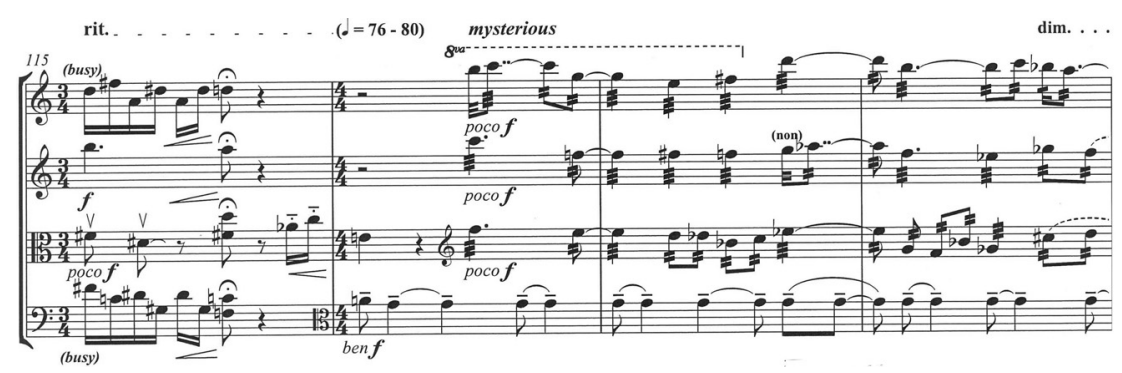

Example 2

Not all moods and emotions are expressed at length; Zaimont seems to favor using two to four measures to form a mood. This is a common characteristic found in songs that also can be heard in Zaimont's quartet. For example, in the first movement of the quartet at measures 215-216, a different texture is introduced; Zaimont uses two short measures to express a violin melodic line in "calming, diminuendo" in simple rhythms with tie-notes accompaniment in violin 2 , viola and cello. The static accompaniment also helps to emphasize the calming mood. Within a very short period, this music passage is immediately followed by an emotion that is indicated with "drag" at measure 217 , in which the four parts are notated in smaller note values of repeating pitches in different rhythmic patterns. The treatment of the rhythm enhances and heightens emotional tension. Sudden alteration of affection and moods from one moment to another are also used to create contrast in the composition. Performers must be aware of the intention of the composer and have the ability to express it in the music.

There are also other moments in the quartet where a combination of moods are introduced in a short music event. For example, in the second movement a "contemplative" mood beginning at measure 106 is used, where the cantabile melody that derived from measure 45 is shortened and followed by a "hesitate" mood indicated in the next measure. Indeed, changes of emotions in the music are often heard in her compositions; she explains that "I do not stay at any one dynamic or emotional level for very long. My pieces probably are at a rather high emotional pitch rather than being passive, and therefore the music is dramatic and theatrical." ${ }^{11}$ Every creative move she makes in her music demonstrates her keenness for expressiveness and communication. "I think of my pieces as both documents of expression (mine) and of communication (making a bridge to the listener)," said Zaimont. ${ }^{32}$

${ }^{31}$ Baird, “The Choral Music of Judith Lang Zaimont," 26.

${ }^{32}$ Zaimont, "Being a Composer." 
Similarly, in Zaimont's songs informative indications and techniques are used to achieve a creative interpretation of texts. This is seen in her Nattens Monolog. For example, a moment of rapid change of mood is heard in the music when an instruction, "Recitative - Hurried", is given, to which is attached a text, "until around me was an infinity into which we all flowed together and lived" to be sung in different rhythmic activity of sixteenth notes, triplets eighth-notes; this is followed by a different text "a new, a new" in "calming molto ritenuto" in less rhythms. Zaimont shows her fascination with poetic fantasy and mystery.

Indeed, Zaimont's music encompasses a greater range of expressions and moods in her powerful individual idioms. She tries every possible way to generate moods in her instrumental music, as she presents text interpretation in her songs. She seeks for music that fills with intense emotion and passion. In her vocal works, she carefully sets texts and poems, giving instructions and changing texture to set a certain mood that should immediately trigger a response in the singer. "It's not enough to just frame or mimic a perhaps not-well-thoughtthrough reading of the words. Any musical setting makes definite one particularized reading of the words. A couple of times I've set the same text myself, more than once. So I know that texts are susceptible of many interpretations." 33 Zaimont is also cautious in her text selection. "I do not like poetry that is a narrative. I like poetry that makes unusual use of coloristic adjectives. I love the poetry of a poet like Shapiro who can write on many different levels within the same poem, not all thundering on one hand or reflective on the other." ${ }^{34}$ One also witnesses a similar approach in Zaimont's quartet. As in her songs, The Figure quartet contains a wide range of expressions, sound effects and colors, and styles to provide various musical imagery.

In most of her instrumental scores further ideas of interpretation are often included for effect and sound colors. Similarly, in her vocal works, singers should not assume that simply to follow the given general emotional instructions is enough; some detailed performing cues are added on the scores. In her Virgie Rainey, for instance, not only does Zaimont mark "hesitant" in the music and use breath markings and pauses to emphasize the texts, but also performance cues such as "stretch" and "long" are given for singers, enlarging the expressive vocabulary of the performer (Example 3). This is also a music character and approach of Zaimont's writing style in both vocal and instrumental genres, in which she aims to contain more emotional scope in her music. As Zaimont also remarks, "composers rightly stipulate that it's not enough to play the notes, rhythms and

${ }^{33}$ Llewellyn, "Amy Beach and Judith Lang Zaimont," 443.

${ }^{34}$ Linda McNeil, "The Vocal Solo Works of Judith Lang Zaimont: An Annotated Bibliography" (D.M.A. diss., Arizona State University, 1988), 76. 
dynamics accurately - you have to play the inner music also, and deliver all in that composer's specific, intended manner." ${ }^{35}$

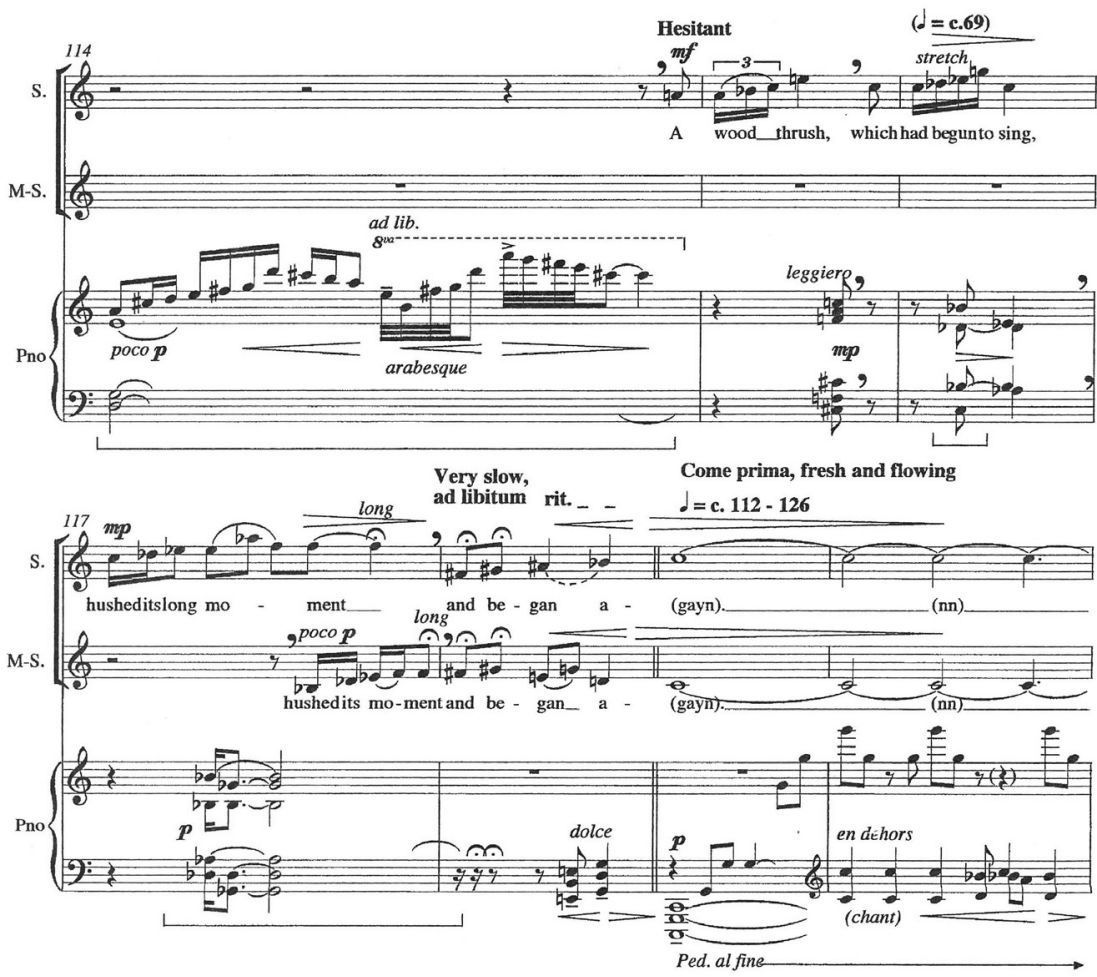

\section{Example 3}

Throughout the quartet there are many moments at which attention is given to a short expressive melodic idea and passages through specific guidelines, instructions and indications such as "not busy," intense," "quietly," "relax," "harsh" with which it is to be played. These instructions fill the music with passion, intensity, lyricism and beauty, which not only creates different moods, sound colors and effects, but it also gives performers pleasure to play. Similarly, in Zaimont's songs vocalists are given many specific, direct instructions such as "freely," "not loud," "more intense, never loud," "somewhat stern but legato," "very calm" and

${ }^{35}$ Judith Lang Zaimont, "Straight Talk on New Notes." Invited Address for College Music Society, national conference special session, October 2003. (Accessed: 24 July, 2017) http://www.jzaimont. com/bibliography/bibliography-cms-miami.html 
"pointed, worried" on how to sing the line, and thereby create and control intense emotion. To Zaimont, music should be made interesting to everyone. She asserts that "it's not enough for a piece to be a document of the composer's creative vision: it must also, in some valid sense, feel 'good / exciting' to play." 36

Moreover, dramatic contrasts are flexibly created through dynamics and different sound effects in The Figure quartet. For instance, after a break at the end of an event with a gradually decreasing dynamic and a "relax" mood indication at measure 36 in the second movement, there is a sudden change to an "intense" mood for two measures in forte. This intense energy soon returns to less rhythmic activity and long-note values in mezzo piano with a "relax" mood indicated by Zaimont at measure 39. Like in her Nattens Monolog, different feelings are set in the music to interpret the emotions given in the text of her song. For instance, Zaimont elucidates the lyric "How seldom growth and blossom, How seldom fruit", to be sung "freely" and "more tender" in poco forte, followed by a slower, yet intense mood in "Life, In dust In shadow" in mezzo forte, and a "not tense", faster tempo in "Night is drawing night" in mezzo piano. The decrease in dynamic levels also captures the sense and diverse moods of hopelessness portrayed in the text. Zaimont penetrates incisively the connection between the text and mood.

Indeed, Zaimont writes in a particular style of her own. She claims that "I'm of the type of composer who would rather issue enough instructions on the page that takes care of musical matters, but also information that will be helpful in terms of the style of the recreation." ${ }^{37}$ Similar to her songs, in the quartet she provides instructions not only of acceleration, deceleration, ritenuto, expressivo and many others to stretch musical time and to emphasize emotion, but also the expressiveness is extended through her indications on the score. Zaimont has tried to translate feelings and emotions into musical terms. She provides written words, terms and symbol indications not only to express the mood of the music, but also to give styles of playing that imitate and indicate the way a singer might express the music. It is as if Zaimont intended to design the music that evokes the feeling of her imaginary text in this quartet. As an accomplished composer of vocal writing Zaimont is certainly aware that vocal music has been one important medium of musical expression, and there are various musical effects and ideas that can be derived from vocal works.

In the second movement of the quartet Zaimont seeks a more melodic profile, a lyrical melody that is more deeply moving than the melodies in the first movement. An example can be heard at measure 45 where Zaimont is able to create a catchy, brief, singable, lyrical melody out of five pitches: $A \sharp 4-F \# 4-E \sharp 4-C \sharp 5-A \# 4$.

\footnotetext{
${ }^{36}$ Brumbeloe, "A Conversation with Judith Lang Zaimont."

${ }^{37}$ Llewellyn, "Amy Beach and Judith Lang Zaimont," 446.
} 
Indeed, being a prolific composer in vocal writing, it is not surprising that expressiveness and lyrical melodies have been one of Zaimont's main musical languages and a beauty of her compositions. As Kyle Gann remarks, "in some ineffable way they [Zaimont's musical pieces] all sound like her, and all very musical." 38 This cantabile violin melody plays the main role in the passage with other instrumental parts as accompaniment. This manifests itself in the manner in which Zaimont is writing for a vocal part with accompaniment.

At times, a duet kind of "dialogue" is captured in the music that brings to mind songs and operatic works. Zaimont designs a moment of "harsh" in the first movement, beginning at measure 190, where there is a short musical passage in "dialogue" that plays between viola solo (indicated with "heel") and cello solo in staccato (indicated with "uneasy") with recitative accompaniment. Zaimont purposely employs the recitative fashion to emphasize the "dialogue" character in the music. Immediately after the marks of rallentando and "easing", a different mood that is indicated with "drag" occurs at measure 197. It is also introduced in the same recitative style, continuing the "dialogue" style. The use of recitative style is also commonly found in many of Zaimont's piano accompaniments in her vocal music, for instance, her lengthy solo vocal work, Nattens Monolog - Night Soliloquy scena for soprano and piano, her Virgie Rainey and In the Theatre of Night.

Not all instrumental parts in the quartet function as accompaniments to violin like in the piano accompaniment to voice in her vocal works. Instrumental characteristics are experimented with not only to provide technical demand, but also coloristic sounds. "Throughout the quartet each player has many solo moments. Textures are for the most part detailed and complex, and tempo is constantly flexing - so much so that ensemble is as critical an aspect of the work as are its technical and expressive demands", said Zaimont. ${ }^{39}$ Indeed, in her quartet, apart from placing emphasis on violin melody, lyrical solo melodic lines are also given to viola and cello. Various instrumental fashions also are employed to introduce a new idea in the music, giving something different from the previous musical events. For instance, beginning at measure 37 in the first movement Zaimont begins a new idea in thin texture with viola in pizzicato, providing the first downbeat of every measure and cello in staccato playing a melodic line. A similar idea is employed between the violins beginning at measure 52 .

In The Figure quartet, most often the music is less disjunctive and more linear in design. It is as if Zaimont has vocal writing in mind, though it is not without musical complexity. Although many treatments in the quartet remind one of some vocal styles, instrumental idiosyncratic idioms such as harmonics, Bartók

${ }^{38}$ Kyle Gann, "American Composer Profile."

${ }^{39}$ Judith Lang Zaimont, String Quartet: The Figure, Subito Music Publishing. 
snap, sul ponticello, martelé ("hammered" notes) in tremolo, flautendo (flute-like) sound, double-stop pizzicato and others are used to provide a unique listening experience. Virtuosic techniques of triple and quadruple-stops, and footstomp are also included for thicker sound textures and different effects. Sharp textural contrasts are created through alternating linear and chordal passages that use double, triple and quadruple-stops. Sudden dynamic change occurs throughout the composition. There are always unexpected ideas and sound palettes giving freshness to the music.

Nor is there ever a lack of rhythmic momentum in the composition. Not only is there a regular change of meters, triplets and quintuplets, but also polymeters such as 2/4 against 6/8 with different groupings. Strong and weak beats are irregularly emphasized. In the quartet, rhythms are used to create excitement. Scotch snap rhythms are stressed to give fast, agile and energetic moments in the music. These rhythmic articulations are similarly heard in Zaimont's vocal compositions. Interestingly, although trills are commonly used in instrumental music, including this quartet, Zaimont also experiments with two notes in chromatic trill in her voice pieces, adding rhythmic interest to the vocal line. An example can be heard in her Nattens Monolog - Night Soliloquy.

Although Zaimont does not keep the aesthetic goals of minimalism, she widens her expressiveness through this technique. There are no long stretches of time with pitches playing over and over like in typical minimalist works of composers such as Steve Reich and Terry Riley. Zaimont uses the technique to serve her purpose in the music. For instance, in the quartet, there is a continuing fast repeating four-pitch group pattern, beginning at the measure 164 in the first movement in violins; it is reminiscent of an endless and sustaining drone, which is one of the typical minimalist music characters. But Zaimont employs it to create sound color, texture, effect and mood that differ from the previous music, thus differentiating the musical events.

Reiteration pitch patterns are also commonly experimented with in Zaimont's vocal works. An obvious example is her "Flyers" from In the Theatre of Night, in which the text is sung with a repeating pitch with slight pitch alteration in presto (Example 4), drawing the intensity of the mood and the feeling of rushing. In her songs a small group of repeating pitch is also used to begin a text melody, and slightly before a break. This also can be heard in most of Zaimont's songs such as "The Alphabet" from In the Theatre of Night. 


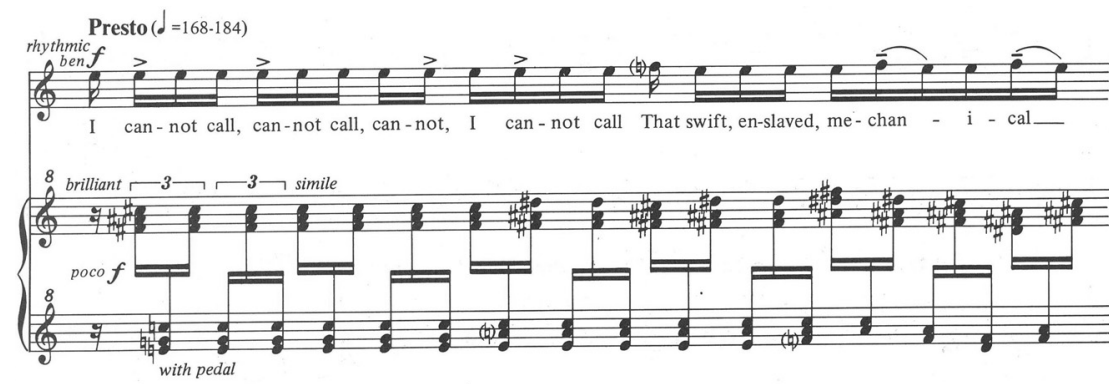

\section{Example 4}

Moreover, a continuously repeating three to four pitches that is heard in the middle of a flowing vocal melodic line is a common song-writing style that is found in vocal compositions and in recitative melodic lines. Nevertheless, one also witnesses Zaimont applying this vocal writing fashion in her The Figure quartet, which has also become a pertinent music character of Zaimont in her instrumental music.

There are also times that one hears various experimental ideas on repeating pitch patterns suggested in the quartet. Most often each reiterate a musical gestural pattern that varies from the previous one to create variety and contrasting musical gestures and ideas in the music. Fragmented passages that reiterate musical gestures are also introduced as an accompaniment for a melody. Such an idea is heard, for example, in a two-part music passage at measures 52-55 in the first movement, where Zaimont employs a short repeating music idea in violin 2 as an accompaniment to violin 1 . This passage varies from its previous four-part music event. Such a compositional idea is also clearly heard in the piano accompaniment of her vocal works such as In the Theatre of Night and Virgie Rainey (Example 5). It is not only one of Zaimont's musical idioms that are often found in her compositions, but this also demonstrates her musical language that is original and personal. 


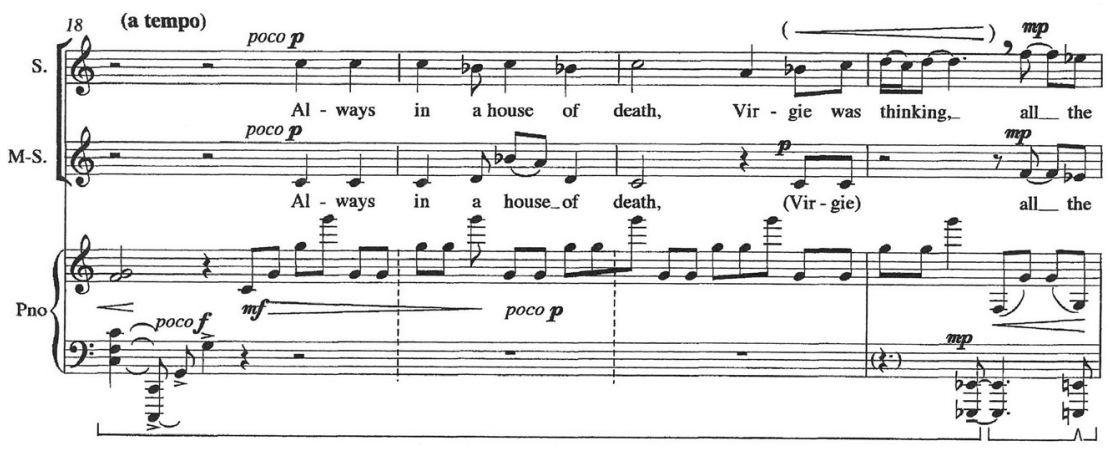

\section{Example 5}

Apart from the exercises of reiterating pitch patterns, repeating rhythmic patterns are also heard in the quartet. For example, in the second movement beginning at measure 31 two rhythmic patterns are held: the viola repeats a four-pitch group in $16^{\text {th }}$-note value, and violins 1 and 2 and cello share a somewhat similar rhythmic pattern (Example 6). Not only does Zaimont present two different rhythmic patterns, but she also contrives two different sound colors in the music: violin in arco with "no weight" indicated, and other instruments play sul ponticello. All these are intended to demonstrate the "quietly" mood in the music.
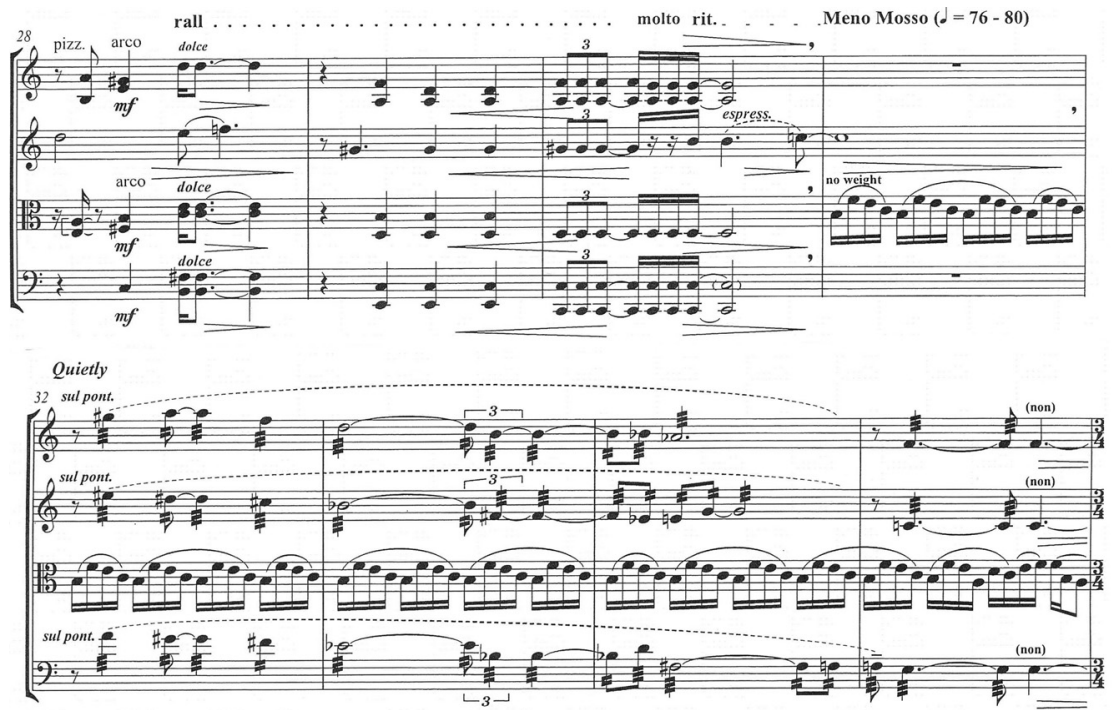

Example 6 
Zaimont also experiments with a repeating pitch idea to intensify the music, creating dramatic and climactic effects. Half way through the music in the first movement several musical sections are built toward a climax. Each climax prepares for the next climax to come as the music progresses. Unlike the normal use of breath markings and pauses in other music events of the quartet, here, eight-note rests or dotted quarter-note rests are used for a short tension release in each climax and setting up for the next. The intense forward moving towards some climaxes is also assisted by a repeating pitch assigned to a string part. The first climax arrives at measure 93 in D6 with sforzando, the second at measure 126 with G6, and Zaimont presents the last and most intense climax in a wide octave range, with $\mathrm{B} 6$ in violin 1 and $\mathrm{C} \$ 2$ in cello at measure 161 in sforzando. In keeping the tension of the final climax in the first movement, a repeat bar-line followed by a footstomp are inserted, sustaining the moment before a measure break is employed to release the tension. This type of one after another climactic building is also heard in "The Alphabet" from In the Theatre of Night. In that piece, Zaimont designs several climactic moments; it is first heard at measure 24 with the high pitch A5 in the vocal part and the next climax occurs at measure 41 in pitch G5 with fortississimo. After each climax Tempo primo is brought back in the next measure, releasing the tension of the music.

A different expressiveness is given at the conclusion of the quartet. It features long-note values in high harmonic sounds in "dim. sempre", which also emphasizes the timbral property of string instruments. Zaimont seems to favor ending her instrumental compositions with harmonic sounds for sound color, for this can be heard at the end of her orchestra pieces such as Stillness and her Symphony No. 4 "Pure, Cool (Water)".

\section{Conclusion}

The quartet is well constructed, with Zaimont's innate dramatic sense of her vocal music revealed in the instrumental composition. Her organization of ideas and reintegration of vocal writing techniques in instrumental music give her music an individual and interesting quality. Although diverse musical ideas and styles are employed, Zaimont's creativity combines and balances them by making them belong together. She attempts to draw closer the relationship between the vocal and instrumental genres, as well to determine the flexibility in an instrumental work. Throughout the composition, technical instrumental writings of rhythmic features, sound colors and textures are included for different purposes; they are employed to differentiate the two music genres in characters, yet, on the other hand, also enhance a variety of moods, emotions and effects that Zaimont intends to project in the music. 
Zaimont is an instinctive melodist; her melodies are brief, yet beautiful. She not only explores the expressive potential in the quartet, but also shows the emotional intensities in the music, which is filled with her imagination. In the composition one often encounters immediate shifts from one mood or emotion to another. Although a variety of expressive manners are experimented with, the expressions or intense emotions serve the music nicely. Each instrument is designed to "sing" expressively in the music. Instructions are given to sharpen the individual performer's own mental and emotional qualities and be capable of projecting the dramatic situation as indicated. Indeed, musical expressiveness is taken with care; all indications provided are for the purpose of increasing or decreasing emotional intensity. Although an actual text is not included in the composition, Zaimont is able to create intensively dramatic music.

Irregular rhythms, some pauses and rests are meant to be filled with meaning and purposes in the music. Different expression markings, repeating pitches, different dynamic levels, which establish the moods and musical intensity, can all be heard in Zaimont's vocal works. All these have become her music style and characters. The expressive musical language not only shows Zaimont's compositional creativity but also presents a challenging work that provides performers and listeners with imagination.

Ideas and musical gestures employed design the characters of the quartet. It is apparent that the opening two chords and the pitches $\mathrm{C}-\mathrm{B}$ form the unity of the entire composition. Materials and many ideas are generated from the two pitches. The teleological flow is achieved by a climactic design half way through the first movement. The quartet not only provides a different listening experience, but also an understanding of how the composer reveals her individuality. In her music exploration, Zaimont has developed a new relationship between vocal and instrumental music.

\section{Vocal-Instrumental Style in Judith Lang Zaimont's The Figure String Quartet}

\section{Abstract}

This paper explores the distinctive voice of Judith Lang Zaimont in The Figure String Quartet (2007). The composition demonstrates diverse ways of musical handlings that utilize, experiment with and imitate characteristics that are reminiscent of vocal writings. Not only are mood and emotion heavily stressed to create dramatic effects in the composition, but excitement in the music also is created through sound colors and creative musical ideas. Operatic recitative style 
and minimalist's reiteration pitch patterns are also experimented. Throughout the composition irregular rhythms, pauses and rests are have significant meanings and purposes. It is as if Zaimont is writing the music with a text in mind and the work is written for singers. The expressive musical language not only shows Zaimont's compositional creativity but also presents a challenging work that provides opportunity for imagination among both performers and listeners.

\section{Vokálně-instrumentální styl v díle The Figure skladatelky Judith Lang Zaimonth}

\section{Abstrakt}

Článek zkoumá charakteristický styl Judith Lang Zaimont v díle The Figure (2007). Zmíněná kompozice vykazuje specifické strukturální rysy připomínající vokální pojetí. Nejen že zdůrazňuje náladu a emoce, čímž podtrhuje dramatický efekt, vzrušení vychází rovněž ze zvukových barev i kreativních hudebních nápadů. Patrné jsou experimenty s operním recitativním stylem i s minimalismem. Důležitou roli hrají nepravidelné rytmy a pauzy. Nakonec vzniká dojem, že bylo dílo vytvořeno podle existující textové předlohy s určením pro vokální provedení. Výrazný hudební jazyk jednak ukazuje kompoziční kreativitu Zaimont, jednak představuje náročný úkol i př́ležitost interpretům i posluchačům.

\section{Keywords}

Judith Lang Zaimont; The Figure string quartet; $21^{\text {st }}$-century music; vocal-instrumental music

\section{Klíčová slova}

Judith Lang Zaimont; smyčcový kvartet The Figure; hudba 21. století; vokálněinstrumentální hudba

Kheng K. Koay

National Sun Yat-sen University

School of Music, National Sun Yat-sen University

70 Lina Hai Road, 804, Taiwan

kkhengk@yahoo.com; kkhengk@mail.nsysu.edu.tw 